\title{
Factors affecting the non-performing loans in Indonesia
}

\author{
Metya Kartikasary ${ }^{a^{*}}$, Frihardina Marsintaulia ${ }^{a}$ Erla Serlawati ${ }^{a}$ and Sebastianus Laurens ${ }^{a}$
}

\begin{tabular}{|c|c|}
\hline CH RON I C L E & A B S T RA C T \\
\hline $\begin{array}{l}\text { Article history: } \\
\text { Received October } 302019 \\
\text { Received in revised format } \\
\text { November } 252019 \\
\text { Accepted November } 302019 \\
\text { Available online } \\
\text { December } 112019 \\
\text { Keywords: } \\
\text { Non Performing Loan } \\
\text { Financial Ratio } \\
\text { Macroeconomic Variables } \\
\text { Microeconomic Variables }\end{array}$ & $\begin{array}{l}\text { The purpose of this study is to analyze the factors influencing non-performing loans in companies listed on the } \\
\text { Indonesian Stock Exchange Banking sector. All banks in Indonesia carefully review their Non-Performing Loans. } \\
\text { According to the Central Bank regulations, the non-performing loan is at a maximum of } 5 \% \text {. Exceed the percentage; } \\
\text { there will be one of the indications that the bank is experiencing difficulties and could potentially endanger business } \\
\text { continuity. The researchers use the micro-economic and several macro-economic variables to predict the } \\
\text { influencing factors toward the non-performing loan. Microeconomic variables studied are the ratio of bank capital } \\
\text { to assets (CAP), the loans to deposits (LTD) ratio, the return to assets (ROA) ratio and the ratio of return to equity } \\
\text { (ROE). Macroeconomic variables are the ratio of public sector debt to gross domestic product (DEBT), the surplus } \\
\text { or deficit of the government budget to gross domestic product (FISCAL) ratio, the percentage increase in gross } \\
\text { domestic product (GDP), annual inflation rate (INFL), and percentage of job seeker level (UNEMP). Researchers } \\
\text { used some regression methods to analyze the results and the samples taken by researchers were companies listed } \\
\text { in the banking sector during the period 2014-2017, and macroeconomic data in Indonesia during that year. }\end{array}$ \\
\hline
\end{tabular}

(C) 2020 by the authors; licensee Growing Science, Canada

\section{Introduction}

Financial statements are information that is structured from the financial position and financial performance of an entity. The financial statements aim to provide information about the financial position, financial performance and cash flow of the entity that are useful for users of financial statements in decision making. One component in the banking sector financial statements that needs to be considered important is loans to third parties. Increasing loan to consumers is a form of competition among banking companies in Indonesia. This increase will also affect the increased risk of bad credit. One measure to determine the risk of bad credit is the Non-Performing Loan (NLP). Since 2008, the beginning of the global financial crisis, the level of NPL has increased significantly. In fact, according to analysts, the number of NPLs is expected to increase greatly within the next few years, which can affect the liquidity and profitability of banks and thus creates some challenges for a country as a whole. According to Bank of Indonesia regulations, banks that have an NPL ratio more than 5\% are considered to have difficulties in maintaining business continuity. If a bank is deemed to have difficulties then the bank must be monitored with incentives. This is what needs to be maintained by banks in Indonesia so that it would not happen in future.

\section{Previous Studies}

In Europe, Fiordelisi et al. (2011) econometrically identified loan losses through various banking and macroeconomic factors, using panel data of Spanish commercial banks and savings for the 1985-1997 period. This study shows that the growth rate of gross domestic product (GDP) had a negative effect on non-performing loans, confirming that during a recession, nonperforming loans increase. They also concluded that bank size was negatively related to problemed loans, while credit growth,

* Corresponding author

E-mail address: metya kartikasary@yahoo.com (M. Kartikasary) 
collateral loans, net interest margins, and market strength were positively related. Examining a sample of 1,927 Italian banks for the 2006-2008 period, Cotugno et al. (2010) found that the average rate was positively correlated with bank size, gross loans and functional distance, and negatively related to asset returns (ROA) and $\triangle$ GDPt. Regarding Greek banking, Louzis et al. (2012) examined the effects of various macroeconomic and banking-specific factors on the NPL, also studied each type of loan in the nine largest Greek banks both overall and separately, for the period 2003Q1-2009Q3. They found that GDP growth rates, unemployment rates and loan rates had strong opposite directions on the NPL level, as did return on equity (ROE) and ROA indicators, which can be interpreted as a sign of bad bank management. In addition, Nkusu (2011) analyzed the relationship between nonperforming loans and macroeconomic performance of 26 developed countries from 1998 to 2009. In his study, only macroeconomic variables were introduced. Specifically, GDP growth, unemployment, changes in the house price index, changes in the equity price index, inflation, nominal effective exchange rates, interest rate and credit policies for the private sector were included in his empirical specifications. His findings revealed that poor macroeconomic performance (e.g. slower GDP growth, higher unemployment or falling asset prices) can be associated with an increase in problem loans in developed countries.

In contrast to Nkusu (2011), the study of De Bock and Demyanets (2012) analyzed the determinants of the quality of bank assets in 25 developing countries during 1996-2010, by only examining macroeconomic indicators and aggregate credit. Their findings presented that GDP growth rates, exchange rates and loan growth were the main determinants of bad credit in the countries examined. Based on the studies above, it can be seen that the macro economy (e.g. unemployment, house price index, inflation, lending rates, growth credit) and bank specific factors (e.g. profitability ratios, capital adequacy, bank measures and ownership) seem to determine the quality of the loan portfolio. Thus, this study will examine the impact of macroeconomic and bank specific factors on banking companies listed on the Indonesia Stock Exchange in 2014-2017. This study developed research from Makri et al. (2014) which examined the microeconomic and macroeconomic factors in their effects on NPL in European countries. This study obtained data and sources from banking companies in Indonesia, to determine the factors that influence NPLs that illustrate the risk of bad credit in Indonesia in 2014-2017. The study is expected to show that the microeconomic factors including bank capital to asset ratio (CAP), loan to deposit ratio (LTD), return to asset ratio (ROA), return to equity ratio (ROE), and Macroeconomic variables to be examined such as the ratio of public sector debt to gross domestic product (DEBT), the ratio of surplus or deficit of the government budget to gross domestic product (FISCAL), the percentage of increase in gross domestic product (GDP), annual inflation rate (INFL) and the percentage of job seekers' level (UNEMP) significantly influence on NPL.

\section{Methods}

The research type is a descriptive design for the sample, and then tabulates the population on the information contained in the sample. The method used for hypothesis testing in this study is the regression method with panel data (pooled regression) with SPSS. This method was chosen because the research data structure is panel data (data collected in cross section and followed at a certain time period). The data were collected from audited annual financial statements of Banking sector listed on the Indonesia Stock Exchange from 2014-2017, previous studies, scientific journals, articles, books, and the worldwide web. Initially, there were 43 companies included in this study.

\section{Research Conceptual Framework}

\subsection{Factors affecting Non-Performing Loan}

This study measures macroeconomic factors and bank specific factors to determine their effects on NPL. The factors to be investigated are:

\begin{tabular}{|c|c|c|}
\hline Symbol & Explanation & Expected sign \\
\hline \multicolumn{3}{|c|}{ Bank Specific Factors } \\
\hline NPL & Aggregate non-performing loans to total gross loans & $(+)$ \\
\hline CAP & Bank capital and reserves to total assets & $(-) /(+)$ \\
\hline LTD & Loans to deposit ratio & $(+)$ \\
\hline ROA & Return on assets & $(-)$ \\
\hline ROE & Return on equity & $(-)$ \\
\hline \multicolumn{3}{|c|}{ Macroeconomic Factors } \\
\hline DEBT & Public debt as percentage of GDP & $(+)$ \\
\hline FISCAL & Government budget deficit or surplus as percentage of GDP & $(-)$ \\
\hline GDP & Annual percentage growth rate of GDP & $(-)$ \\
\hline INFL & Annual average inflation rate & $(+) /(-)$ \\
\hline UNEMP & Percentage of unemployment & $(+)$ \\
\hline
\end{tabular}

These factors were adapted from previous studies, namely research conducted by Makri et al. (2014) in the Eurozone banking system. The study identifies which factors influence the level of NPL in 43 banking companies in Indonesia in the period 20142017. 
Tests that consider the specific internal factors of the banks studied are: Capital Adequacy Ratio (CAP), Loans to Deposits (LTD), Return on Assets (ROA), Return on Equity (ROE) and NPL of the previous year. CAP or Capital Adequacy Ratio is used to measure the risk that can be created by the company from the company's capital adequacy. CAP testing of NPL was research by Makri et al. (2014) showed the positive effect of CAP on NPL. Test LTD or Loans to Deposit, which illustrates the relationship between loans and deposits is very important to examine bank liquidity by comparing the funds used by banks to provide loans to consumers, and funds received by banks from customer deposit deposits. According to previous studies such as Louzis et al. (2012) and Misra and Dhal (2010), Makri et al. (2014) the LTD level is expected to have a positive effect on NPL. Apart from the above factors, researchers also examine profitability ratios (ROA and ROE variables). Bank profitability is related to bank risk taking behavior. Banks that have a higher profit level are considered not to carry out activities that have risky activities, (Makri et al., 2014). ROA and ROE are expected to show a negative influence on NPL. To test the persistence of problem loans, the researchers also used the level of non-performing loans (NPLt-1) as an independent variable and they also expected a positive correlation. NPL level measurement is measured from the average NPL to total gross loans. Hereafter, the researchers investigated the effects of various macroeconomic factors on the dependent variable. According to Espinoza and Prasad (2010), the previous crisis revealed the importance of linking macroeconomic variables to the stability of the banking system. In this context, we add variables: GDP, inflation rate (INFL), unemployment rate (UNEMP), public debt as percentage of GDP (DEBT), and government budget deficit or surplus as percentage of GDP (FISCAL), to capture economic conditions prevailing in Indonesia in the 2014-2017 period and how they affect the NPL index. The GDP and UNEMP variables are needed to describe the existing economic activities and see the effect of the business cycle on loan quality. It is widely accepted that a healthy economic environment can be associated with increased income and reduced unemployment. As a result, researchers expect a positive relationship between NPL and unemployment and a negative correlation with GDP. In addition, the INFL variable stands for annual average inflation rate, which affects the ability of borrowers to repay their loans. According to Nkusu (2011) the impact of inflation on loan quality can be ambiguous, thus it can be shown either a negative or positive relationship with NPL. In some European countries, the current crisis first affects the fiscal index and then extends to banks. Taking this into account, public financial variables (FISCAL and DEBT) were also included in our investigation. Researchers anticipate a positive relationship between loan quality and public debt and a negative relationship with the government budget deficit / surplus. This is because the FISCAL variable basically has an opposite relationship to the DEBT, so this is expected to provide a negative correlation with NPL. Based on the framework described previously, the researcher develops the hypothesis as follows:

1. Identifying the relationship between company-specific internal factors (CAP, LTD, ROA, ROE, NPLt-1) and NPL.

2. Identifying the relationship between Indonesian macroeconomic factors (DEBT, FISCAL, GDP, INFL, UNEMP) and NPL.

3. Identifying the relationship between company-specific internal factors (CAP, LTD, ROA, ROE, NPLt-1) and Indonesian macroeconomic factors (DEBT, FISCAL, GDP, INFL UNEMP) simultaneously that affect NPL.

\section{Results and discussion}

This section presents the results of data analysis based on observing a number of variables used in the regression model. The study involves the dependent variable namely non-performing loans (NPLs) and independent variables namely company specific internal factors such as Bank capital and reserves to total assets (CAP), Loans to deposit ratio (LTD), Return on assets (ROA), Return on equity (ROE), aggregate non-performing loans to total gross loans t-1 (NPLT1), Public debt as percentage of GDP (DEBT), Government budget deficit or surplus as\% of GDP (FISCAL), Annual percentage growth rate of GDP (GDP), Annual average inflation rate (INFL), Percentage of unemployment (UNEMP). Panel data regression research model as follows:

Hypothesis A:

H0.A: Specific internal factors of the company have positive relationship with NPL.

H1.A: Company specific internal factors have negative relationship with NPL.

The multiple linear regression analysis models used is as follows:

$\mathrm{NPL}=\beta_{\mathrm{O}}+\beta_{1} \mathrm{CAP}+\beta_{2} \mathrm{LTD}+\beta_{3} \mathrm{ROA}+\beta_{4} \mathrm{ROE}+\beta_{5} \mathrm{NPL}_{\mathrm{t}-1}+\varepsilon_{\mathrm{i}}$

Hypothesis B:

H0.B: Macroeconomic factors have positive relationships with NPL.

H1.B: Macroeconomic factors have negative relationships with NPL.

The multiple linear regression analysis models used is as follows, 
$\mathrm{NPL}=\beta_{\mathrm{O}}+\beta_{1} \mathrm{DEBT}+\beta_{2}$ FISCAL $+\beta_{3}$ GDP $+\beta_{4}$ INFL $+\beta_{5} \mathrm{UNEMP}+\varepsilon_{\mathrm{i}}$

Hypothesis C:

H0.C: Specific internal factors of the company and macroeconomic have positive relationships with NPL.

H1.C: Specific internal factors of the company and Indonesia's macroeconomic have negative relationships with NPL.

The multiple linear regression analysis models used is as follows,

$\mathrm{NPL}=\beta_{\mathrm{O}}+\beta_{1} \mathrm{CAP}+\beta_{2} \mathrm{LTD}+\beta_{3} \mathrm{ROA}+\beta_{4} \mathrm{ROE}+\beta_{5} \mathrm{NPL}-1+\beta_{6} \mathrm{DEBT}+\beta_{7}$ FISCAL $+\beta_{8} \mathrm{GDP}+\beta_{9}$ INFL $+\beta_{10} \mathrm{UNEMP}+\varepsilon_{\mathrm{i}}$

Description:

NPL = Aggregate non-performing loans to total gross loans

CAP $=$ Bank capital and reserves to total assets

LTD = Loans to deposit ratio

ROA $=$ Return on assets

ROE = Return on equity

$\mathrm{NPL}_{\mathrm{t}-1}=$ Aggregate non-performing loans to total gross loans $\mathrm{t}-1$

DEBT = Public debt as percentage of GDP

FISCAL $=$ Government budget deficit or surplus as percentage of GDP

GDP = Annual percentage growth rate of GDP

$\mathrm{INFL}=$ Annual average inflation rate

$\mathrm{UNEMP}=$ Percentage of unemployment

A good regression model is appropriate if it fulfills several assumptions. After fulfilling the classical assumptions that exist, then a variable is feasible to be used for the purpose of predicting other variables. The regression model that can predict the dependent variable based on the input of the independent variable is a regression model that meets the assumption of normality and does not occur multicollinity, autocorrelation and heteroscedasticity.

\section{Adjusted $R^{2}$}

The coefficient of determination $\left(\mathrm{R}^{2}\right)$ essentially measures how far the model's ability to explain the variation of the dependent variable. The coefficient of determination is between zero and one. A small Adjusted $\mathrm{R}^{2}$ value means that the ability of the independent variables in explaining the variation of the dependent variables is very limited. In general, the coefficient of determination for cross section data is relatively low because of the large variations between each observation. Many researchers recommend the Adjusted $\mathrm{R}^{2}$ value when evaluating which regression model is best. The adjusted $\mathrm{R}^{2}$ value can go up or down if an independent variable is added to the model. From the computational results of research data using SPSS software, the Adjusted $\mathrm{R}^{2}$ statistical parameters are obtained as follows:

\section{Table 1}

Summary of Three Model Results

\begin{tabular}{lccc}
\hline \multicolumn{1}{c}{ Model } & R & Adjusted R $^{2}$ & Sig \\
\hline 1. CAP, LTD, ROA, ROE, NPLT1 & 0.707 & 0.499 & 0.000 \\
2. DEBT, FISCAL, GDP, INFL, UNEMP & 0.186 & 0.018 & 0.108 \\
3. CAP, LTD, ROA, ROE, NPLT1, DEBT, FISCAL, GDP, INFL, UNEMP & 0.713 & 0.484 & 0.000 \\
\hline
\end{tabular}

The test criteria performed were:

1. Accept $\mathrm{H}_{0}$ and reject $\mathrm{H}_{1}$ if $\operatorname{Sig}(\alpha)>0.050$

2. Reject $\mathrm{H}_{0}$ and accept $\mathrm{H}_{1}$ if $\operatorname{Sig}(\alpha)<0.050$

Based on the value of the statistical parameter adjusted $\mathrm{R}^{2}$, the dependent variable (NPL) is influenced by the variation of the independent variable, namely company specific internal factors and simultaneously specific internal factors and Indonesian macroeconomic factors, which can affect NPL. The first model aims to identify the influence of company-specific internal factors on the NPL dependent variable. The results showed a significant influence of company-specific internal factors on NPL. The value of Adjusted $\mathrm{R}^{2}$ is 0.499 , meaning that $49.9 \%$ of NPL can be explained by specific factors internal to the company (CAP, LTD, ROA, ROE, NPLT1). The second model aims to identify the effects of Indonesia's macroeconomic factors. The results showed no influence of macroeconomic factors on NPL. The value of Adjusted $\mathrm{R}^{2}$ is 0.018 , meaning $1.8 \%$ NPL can be 
explained by macroeconomic factors (CAP, LTD, ROA, ROE, NPLT1). The third model aims to identify the influence of specific internal factors of the company and Indonesia's macroeconomic with NPL. The value of adjusted $\mathrm{R}^{2}$ is 0.484 , meaning that $48,4 \%$ of NPL can be explained by macroeconomic factors (CAP, LTD, ROA, ROE, NPLT1).

\section{Assumption Test}

\section{Multicollinearity Test}

Multicollinearity test aims to test whether the regression model found a correlation between independent variables (independent). A good regression model should not occur correlation between independent variables.

Table 2

Multicollinearity Test

\begin{tabular}{|c|c|c|c|}
\hline \multirow{2}{*}{\multicolumn{2}{|c|}{ Model }} & \multicolumn{2}{|c|}{ Collinearity Statistics } \\
\hline & & Tolerance & VIF \\
\hline \multirow{9}{*}{1} & Constant & & \\
\hline & CAP & .869 & 1.151 \\
\hline & LTD & .943 & 1.060 \\
\hline & ROA & .179 & 5.576 \\
\hline & ROE & .192 & 5.208 \\
\hline & DEBT & .218 & 4.594 \\
\hline & GDP & .262 & 3.823 \\
\hline & UNEMP & .360 & 2.776 \\
\hline & NPLT1 & .760 & 1.316 \\
\hline
\end{tabular}

Based on the results of multicollinearity test as seen in Table 2, it can be concluded that there is no correlation between independent variables in the regression model or multicollinearity does not occur. This conclusion was drawn because the tolerance values for the models for CAP, LTD, ROA, ROE, NPLT1, DEBT GDP INFL were 0.869, 0.943, 0.179, 0.192, 0.760, $0.218,0.262,0.360$ which were greater than 0.1 and based on VIF values respectively are $1,151,1,060,5,576,5,208,4,594$ which are smaller than 10 .

\section{Heteroscedasticity Test}

The heteroscedasticity test aims to test whether in the regression model there is an inequality of variance from the residuals of one observation to another. A good regression model is Homoscedasticity or heteroscedasticity does not occur. To detect the presence or absence of heteroscedasticity by looking at the plot graph between the predicted value of the dependent variable (ZPRED) and the residual SRESID.

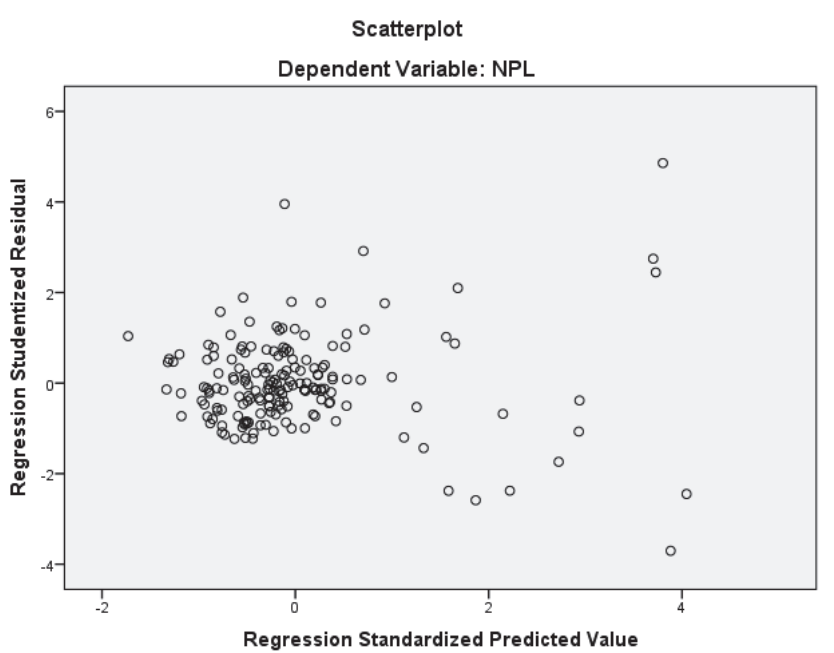

Fig. 1. Scatterplot Heteroscedasticity Test

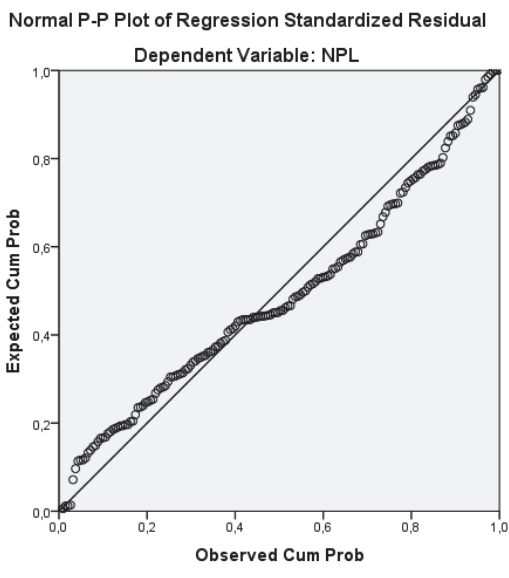

Fig. 2. Histogram Normality test 
Based on the Scatter-Plot figure, the data is concluded that there is no clear pattern, and the points are spread so it can be concluded that heteroscedasticity does not occur. Thus, all independent variables are free from testing classical assumptions so that they do not need to be excluded from the regression model.

\section{Normality test}

Normality test aims to determine whether in the regression model, confounding or residual variables have normal distribution. In principle, normality can be detected by looking at the spread of data (points) on the diagonal axis of the graph or by looking at the histogram of the residuals. Fig. 2 shows that the data spreads around the diagonal line and follows the direction of the diagonal line or the histogram graph shows the normal distribution pattern, the regression model used meets the normality assumption.

\section{Autocorrelation Test}

The autocorrelation test aims to test whether in the linear regression model there is a correlation between the error of the intruder in the $t$ period and the error of the intruder in the $\mathrm{t}-1$ period (before). A good regression model is a regression that is free from autocorrelation.

Table 3

Durbin-Watson Test

\begin{tabular}{lcc}
\hline Model & Std. Error of the Estimate & Durbin-Watson \\
\hline 1 & 1.585389 & 2.163 \\
\hline
\end{tabular}

Based on Table 3, the DW value obtained from the regression model is 2.163 while the DW table with a significance of 0.05 and the amount of data $(\mathrm{n})=176$ and $\mathrm{k}=10$ ( $\mathrm{k}$ is the number of independent variables) obtained dL value of 1.6350 and dU of 1.8745 (see DW table). Because the DW value of 2.163 is in the area above $\mathrm{dL}$ and dU it means that there is no autocorrelation.

Hypothesis test

Model 1 Testing Results: Specific Internal Factors of NPL

Table 4

t-Test Result Specific Internal Factors

\begin{tabular}{|c|c|c|c|c|c|c|}
\hline \multirow[t]{2}{*}{ Mod } & & \multicolumn{2}{|c|}{ Unstandardized Coefficients } & \multirow{2}{*}{$\begin{array}{c}\text { Standardized } \\
\text { Coefficients } \\
\text { Beta }\end{array}$} & \multirow[t]{2}{*}{$\mathrm{t}$} & \multirow[t]{2}{*}{ Sig. } \\
\hline & & B & Std. Error & & & \\
\hline \multirow{6}{*}{1} & (Constant) & 1.307 & .873 & & 1.498 & .136 \\
\hline & CAP & -.017 & 018 & -.053 & -.945 & .346 \\
\hline & LTD & .018 & .009 & .112 & 2.002 & .047 \\
\hline & ROA & -.111 & 101 & -.140 & -1.098 & 274 \\
\hline & ROE & -.044 & .015 & -.374 & -3.045 & .003 \\
\hline & NPLT1 & .293 & .058 & .308 & 5.032 & .000 \\
\hline
\end{tabular}

Based on research model 1, regression research model as follows:

$$
\mathrm{NPL}=1.307-0.017 \mathrm{CAP}+0.018 \mathrm{LTD}-0.111 \mathrm{ROA}-0.044 \mathrm{ROE}+0.293 \mathrm{NPL}_{\mathrm{t}-1}+\varepsilon_{\mathrm{i}}
$$

Then the partial regression model from the test results can be explained as follows:

1. Capital Adequate Ratio (CAP) has a Sig. value of 0.346, which is greater than 0.05 with a regression coefficient of -0.017 so that HoA is rejected. This shows that the CAP does not have a positive influence on NPL. The results of this study are not in line with the studies of Makri et al. (2014) which shows the positive influence of CAP on NPL. The CAP value in the linear equation is minus, that is -0.024 . This states that the more the CAP increases, the NPL will decrease. In this study, the decline in NPL was caused by the increasing ability of the bank to bear the risk of any risky credit or productive assets. The increase in the ability of the bank was triggered by the increase in bank capital itself and other sources from outside the bank such as increased funds from the public, loans and others.

2. LTD has sig. value of 0.047 , which is greater than 0.05 with a regression coefficient of 0.018 so that the HoA is accepted. This shows that LTD has a positive influence on NPL. The results of this study are in line with the studies of Louzis et al. (2010), Misra and Dhal (2010) and Makri et al. (2014) which show the level of LTD which results in a positive effect on NPL. The LTD value in the linear equation is positive, which is 0.047 . This states that as LTD increases, the NPL will also increase. This can occur because the third-party funds collected in the form of demand deposits, savings, and deposit 
deposits increase. As more third-party funds are collected, there will also be a lot of lending to creditors, which will lead to an increase in the distribution of credit funds and the possibility of bad loans will also increase.

3. ROA has a Sig. value of 0.274 , which is greater than 0.05 with a regression coefficient of -0.111 so HoA is rejected. This shows that ROA has no negative effect on NPL. The results of this study are not in line with the studies of Makri et al. (2014) which show ROA has a negative influence on NPL. The ROA value in the linear equation is negative, that is -0.106. This states that the more the value of ROA increases the NPL value decreases. This can occur because banks that have a higher level of profit are considered not to carry out activities that have risky activities.

4. ROE has a Sig. value of 0.003 which is smaller than 0.05 with a regression coefficient of -0.044 so that the HoA is accepted. This shows that ROE has a negative influence on NPL. The results of this study are in line with the studies of Makri et al. (2014) which show ROA has a negative influence on NPL. The ROE value in the linear equation is negative, that is -0.044 . This can happen because even if there is an increase in the level of profitability of the bank, the bank will carefully manage profits with a consideration that is not detrimental, screening credit applications according to the rules and the right analysis in determining the right lending.

5. NPLT1 has a value of sig. 0,000 , which is smaller than 0.05 with a regression coefficient of 0.293 so that the HoA is accepted. This shows that (NPLt-1) has a positive influence on NPL.

Table 5

F-Test Result: Specific Internal Factors

\begin{tabular}{llccccc}
\hline Model & & Sum of Squares & df & Mean Square & F & Sig. \\
\hline \multirow{2}{*}{1} & Regression & 425.870 & 5 & 85.174 & 33.891 & $.000^{\mathrm{b}}$ \\
& Residual & 427.245 & 170 & 2.513 & & \\
\cline { 2 - 7 } & Total & 853.115 & 175 & & \\
\hline
\end{tabular}

The F statistical test basically shows whether all the independent or independent variables entered in the model have a joint influence on the dependent variable. From the overall test (simultaneous) results obtained as shown in the table that the F value of 33.891 with a sig value of 0.000 is smaller than 0.05 . These results indicate that there is a joint effect between the independent variables with the dependent variable. Thus, for CAP, LTD, ROA, ROE, NPLT1 together affect the NPL. The coefficient of determination $\left(\mathrm{R}^{2}\right)$ is $49.9 \%$ NPL influenced by CAP, LTD, ROA, ROE and NPLt- 1 , where the remaining $50.1 \%$ is determined by other factors outside the research model.

Model 2 Testing Results: Indonesian Macroeconomic Factors of NPL

Table 6

t-Test Result: Indonesian Macroeconomic Factors

\begin{tabular}{|c|c|c|c|c|c|c|}
\hline \multirow[t]{2}{*}{ Model } & & \multicolumn{2}{|c|}{ Unstandardized Coefficients } & \multirow{2}{*}{$\begin{array}{c}\text { Standardized } \\
\text { Coefficients }\end{array}$} & \multirow[t]{2}{*}{$\mathrm{t}$} & \multirow[t]{2}{*}{ Sig. } \\
\hline & & $\mathrm{B}$ & Std. Error & & & \\
\hline \multirow{4}{*}{1} & (Constant) & 9.267 & 4.771 & & 1.942 & .054 \\
\hline & DEBT & 1.129 & 2.752 & .065 & .410 & .682 \\
\hline & GDP & .167 & .170 & .141 & .980 & .328 \\
\hline & UNEMP & -1.753 & .974 & -.214 & -1.801 & .074 \\
\hline
\end{tabular}

Based on research model 2, regression research model as follows:

$$
\mathrm{NPL}=0.267+1.129 \mathrm{DEBT}+0 \mathrm{FISCAL}+0.167 \mathrm{GDP}+0 \mathrm{INFL}-1.753 \mathrm{UNEMP}+\varepsilon \mathrm{i}
$$

Obtained data processing results as follows:

For overall macroeconomic factor variables, it shows that individually macroeconomic variables have no influence on NPL, the following explanation:

1. DEBT has Sig. value of 0.682 which is greater than 0.05 with a regression coefficient of 1.129 and thus we can conclude that the HoB is rejected. This shows that DEBT does not have a positive influence on NPL. DEBT value in the positive equation linear equation is 1.129 . This states that if DEBT increases, NPL will also increase. 
2. FISCAL. When processing data, the FISCAL variable is included in the excluded variables the relationship between FISCAL and NPL cannot be explained.

3. GDP has sig. value of 0.328 , which is greater than 0.05 with a regression coefficient of 0.167 and the HoB is rejected. This shows that GDP does not have a negative influence on NPL. The value of GDP in the linear equation is positive 0.167 , which means that if GDP increases, the NPL will increase as well.

4. INFL. When processing data, the INFL variable is included in the excluded variables so that the relationship between INFL and NPL cannot be explained.

5. UNEMP has a sig.0,074 value that is greater than 0.074 with a regression coefficient of -1.753 so that the HoB is rejected. This shows that UNEMP does not have a positive influence on NPL. The UNEMP value in the linear equation is negative $-1,753$, which means that if UNEMP increases, the NPL will increase.

Table 7

F-test Result: Indonesian Macroeconomic Factors

\begin{tabular}{llccccc}
\hline Model & & Sum of Squares & df & Mean Square & F & Sig. \\
\hline \multirow{2}{*}{1} & Regression & 29.494 & 3 & 9.831 & 2.053 & \\
& Residual & 823.621 & 172 & 4.788 & \\
\cline { 2 - 7 } & Total & 853.115 & 175 & & \\
\hline
\end{tabular}

From the overall test (simultaneous) the results obtained as shown in Table 7 the $\mathrm{F}$ value of 2.053 with a sig value of 0.108 is greater than 0.05 . These results indicate that there is no joint effect between the independent variables with the dependent variable. Thus, DEBT, GDP, UNEMP jointly influence the NPL. The coefficient of determination $\left(\mathrm{R}^{2}\right)$ is $1.8 \%$ NPL influenced by DEBT, GDP, UNEMP, where the remaining $98.2 \%$ is determined by other factors outside the research model. When processing data, the FISCAL and INFL variables are included in the excluded variables, and also with the GDP variable which shows no significant effect on NPL.

Model 3 Testing Result: Specific Internal Factors and Indonesian Macroeconomic Factors) simultaneously that affect NPL

Based on research model 3, regression research model as follows:

$\mathrm{NPL}=6.097-0.024 \mathrm{CAP}+0.017 \mathrm{LTD}-0.106 \mathrm{ROA}-0.044 \mathrm{ROE}-0.286 \mathrm{NPL}_{\mathrm{t}-1}-0.411 \mathrm{DEBT}+0 \mathrm{FISCAL}+0.033 \mathrm{GDP}+$ $0 \mathrm{INFL}-0.658 \mathrm{UNEMP}+\varepsilon_{\mathrm{i}}$

\section{Table 8}

t-Test Result: Specific Internal Factors and Indonesian Macroeconomic Factors

\begin{tabular}{|c|c|c|c|c|c|c|}
\hline \multirow{2}{*}{\multicolumn{2}{|c|}{ Model }} & \multicolumn{2}{|c|}{ Unstandardized Coefficients } & \multirow{2}{*}{$\begin{array}{c}\text { Standardized } \\
\text { Coefficients } \\
\text { Beta } \\
\end{array}$} & \multirow[t]{2}{*}{$\mathrm{t}$} & \multirow[t]{2}{*}{ Sig. } \\
\hline & & $\mathrm{B}$ & Std. Error & & & \\
\hline \multirow{9}{*}{1} & (Constant) & 6.097 & 3.687 & & 1.653 & .100 \\
\hline & CAP & -.024 & .019 & -.077 & -1.315 & .190 \\
\hline & LTD & .017 & .009 & .108 & 1.924 & .056 \\
\hline & $\mathrm{ROA}$ & -.106 & .102 & -.133 & -1.036 & .302 \\
\hline & ROE & -.044 & .015 & -.369 & -2.978 & .003 \\
\hline & DEBT & -.411 & 2.030 & -.024 & -.202 & .840 \\
\hline & GDP & .033 & .125 & .028 & .261 & .795 \\
\hline & UNEMP & -.658 & .740 & -.081 & -.890 & .375 \\
\hline & NPLT1 & .286 & .059 & .301 & 4.830 & .000 \\
\hline
\end{tabular}

\section{Table 9}

F-Test Result: Specific Internal Factors and Indonesian Macroeconomic Factors

\begin{tabular}{llccccc}
\hline Model & & Sum of Squares & df & Mean Square & F & Sig. \\
\hline \multirow{2}{*}{1} & Regression & 433.367 & 8 & 54.171 & 21.552 & \\
& Residual & 419.748 & 167 & 2.513 & & \\
\cline { 2 - 7 } & Total & 853.115 & 175 & & & \\
\hline
\end{tabular}


From the overall test (simultaneous) results obtained as shown in the table that the F value of 21.552 with a sig value of 0.000 is greater than 0.05 . These results indicate that there is a joint effect between the independent variables with the dependent variable. Thus, for CAP, LTD, ROA, ROE, NPLT1, DEBT, FISCAL, GDP, INFL, UNEMP jointly influence the NPL. The coefficient of determination (R2) is $71.3 \%$ NPL influenced by CAP, LTD, ROA, ROE, NPLT1, DEBT, FISCAL, GDP, INFL, UNEMP where the remaining $28.7 \%$ is determined by other factors outside the research model. When processing data, the FISCAL and INFL variables are included in the excluded variables. In other words, all variables can be used as predictors in the equation model.

\section{Conclusion}

This journal clearly demonstrates how the loan of deposit ratio can significantly influence the non-performing loan of banks in Indonesia. If this ratio is too high, the bank may not have sufficient liquidity to settle any future fund requirements. Conversely, if the ratio is very low, the bank may not be profiting as much as it could be.

The Loan can support investors determine if a bank is managed properly. If the bank does not increase its deposits or its deposits decrease, the bank will have less money to lend. However, if this bank is utilizing debt to finance its lending to the daily operations instead of deposits, the bank will have debt servicing costs since it will need to pay interest on the debt. As a result, a bank that borrows money to lend to its debtors will have lower profit margins and more debt. This will contribute to the bank's non-performing loan. For further research, we may add internal factors and external influences on NPL and broaden the research period.

\section{Acknowledgement}

The authors would like to thank the anonymous referees for constructive comments on earlier version of this paper.

\section{References}

Aprilia, E.C. (2017). Analisis faktor - faktor yang mempengaruhi non performing loan pada perusahaan perbankan yang terdaftar di bank indonesia periode 2011 - 2015, Perbanas.

Barseghyan, L. (2010). Non-performing loans, prospective bailouts, and Japan's slowdown. Journal of Monetary economics, 57(7), 873-890.

Cingolani, M. (2013). Finance capitalism: A look at the European financial accounts. Panoeconomicus, 60(3), $249-290$.

Cotugno, M., Stefanelli, V., \& Torluccio, G. (2010, August). Bank intermediation models and portfolio default rates: what's the relation?. In 23rd Australasian Finance and Banking Conference.

Dash, M. K., \& Kabra, G. (2010). The determinants of non-performing assets in Indian commercial bank: An econometric study. Middle Eastern Finance and Economics, 7(2), 94-106.

De Bock, R., \& Demyanets, M. A. (2012). Bank asset quality in emerging markets: Determinants and spillovers (No. 12-71). International Monetary Fund.

Espinoza, R. A., \& Prasad, A. (2010). Nonperforming loans in the GCC banking system and their macroeconomic effects (No. 10-224). International Monetary Fund.

Fiordelisi, F., Marques-Ibanez, D., \& Molyneux, P. (2011). Efficiency and risk in European banking. Journal of banking \& finance, 35(5), 1315-1326.

Jeong, S., \& Jung, H. (2013). Bank wholesale funding and credit procyclicality: Evidence from Korea. Panoeconomicus, 60(5), 615-631.

Louzis, D. P., Vouldis, A. T., \& Metaxas, V. L. (2012). Macroeconomic and bank-specific determinants of non-performing loans in Greece: A comparative study of mortgage, business and consumer loan portfolios. Journal of Banking \& Finance, 36(4), 1012-1027.

Makri, V., Tsagkanos, A., \& Bellas, A. (2014). Determinants of non-performing loans: The case of Eurozone. Panoeconomicus, 61(2), 193-206.

Misra, B. M., \& Dhal, S. (2010). Pro-cyclical management of banks' non-performing loans by the Indian public sector banks. BIS Asian Research Papers, 16, 1-23.

Nkusu, M. M. (2011). Nonperforming loans and macrofinancial vulnerabilities in advanced economies (No. 11-161). International Monetary Fund.

Zeng, S. (2012). Bank non-performing loans (NPLS): A dynamic model and analysis in China. Modern Economy, 3(01), 100. 
(C) 2020 by the authors; licensee Growing Science, Canada. This is an open access article distributed under the terms and conditions of the Creative Commons Attribution (CC-BY) license (http://creativecommons.org/licenses/by/4.0/). 